\title{
A REVIEW OF MARITIME PATROL AIRCRAFT ROLE IN SUPPORTING INDONESIAN MARITIME SECURITY OPERATIONS
}

\author{
Martin Richard, Leksono Amin Setyo, Widagdo Setyo, Nuh Mohammad \\ University of Brawijaya, Malang, Indonesia \\ *E-mail: ricardmartin0205@gmail.com
}

\begin{abstract}
The general concept of maritime security operations is that the daily presence at sea is carried out by ships and aircraft of the Indonesian Navy's maritime patrol. The maritime patrol pattern used today is the warships as the major element. The warships will carry out patrols in randomly determined sectors. This pattern has many challenges, namely operational planning that is not good and requires a large operating budget, the number of warships and the available budget is limited, and the speed of movement towards the target. The Indonesian Navy Aviation Center has Maritime Patrol Aircraft that have not been used optimally. Extensive and rapid observation is an advantage of aircraft surveillance. KRIs patrolling the area can save fuel by waiting for information from air monitoring patrol aircraft, thereby saving operational costs. In this paper, the assignment of Maritime Patrol Aircraft is optimized based on coverage and operating costs on ideal and real radar conditions using Goal Programming and Fuzzy Inference System (FIS) methods. The optimization results show that the maximum total Coverage Area secured by the Maritime Patrol Aircraft in ideal conditions is wider while in real conditions it is small. The small coverage area is caused by the reduced coverage ability of the radar in real conditions. Mamdani Fuzzy Logic calculation allows us to predict the operational costs that must be incurred if we want a certain coverage area.
\end{abstract}

\section{KEY WORDS}

Maritime patrol aircraft, coverage, operational cost.

Indonesia is the largest archipelago country in the world in terms of its geographic constellation with 17,499 islands and area of 3.25 million $\mathrm{km}^{2}$ of water. Indonesia is also a maritime country when viewed from maritime activities, where the Indonesian people make the sea as a living space as well as a way of life, so that the sea has an important meaning as a unifying medium, transportation media, defense media, and resource extraction media (Hamzah, A. 1984 ). This of course contains a high potential for vulnerability in terms of law and sovereignty. The Indonesian Navy as one of the components of national defense is the guardian and guarantor of the oceans so that it remains safe from the perspective of law and sovereignty by the main tasks carried out by the Indonesian Navy. In connection with the implementation of enforcement of sovereignty and law at sea, the conception of security at sea is compiled to address every incident of violation of sovereignty and law at sea which has legal legality both nationally and internationally. The Indonesian Navy must be able to carry out, early detection of violations by conducting maritime security patrols with elements of the Navy's Integrated Fleet Weapon System (2002). The concept of The Indonesian Navy Operations in the Context of Upholding Marine Sovereignty and Security). The pattern of operations carried out by the Indonesian Navy currently has many challenges, including poor operational planning and requires a fairly large operational budget, a limited number of warships and available budget, the speed of movement towards the target (time response) becomes an obstacle in providing service levels the demands of safeguarding the operating sector.

Thus, it is necessary to think about how to use existing resources as much as possible, so that the achievement of operational results can be optimized. The Indonesian Navy Aviation Center has Maritime Patrol Aircraft that have not been optimally utilized. This is consistent with research conducted by Puntenney, Michael. (1989) in his research entitled 
Optimization Models For Military Aircraft Deployment. Broad and fast observation are an advantage of aircraft surveillance. The warships patrolling the sector can save fuel by waiting for information from air monitoring by patrol planes.

By considering the above problems, it is necessary to have a thought and plan for the assignment of Maritime Patrol Aircraft to support optimal maritime security operations in the eastern region. In this paper, the author tries to optimize the assignment of Maritime Patrol Aircraft Squadron air based on coverage and operating costs using the Goal Programming method and Fuzzy Inference System (FIS). This from the research conducted by Kusumadewi, S., \& Purnomo, H. (2004) with the title of his research entitled Application of Fuzzy Logic for Decision Support. The optimization results obtained can then be used as input in developing a strategy for the projection of the Indonesian Navy's strength.

\section{LITERATURE REVIEW}

Limited marine observation is an activity carried out to obtain information and data on all activities carried out at sea, including fishing; illegal fishing as we know that recently illegal fishing is very much from other countries in the waters of our country and it affects access to fishing. Fish by the small-scale sector is increasingly hindered by the increasing strength of industrial fleets that are often involved illegal, unreported, also raised by Belhabib, D., Sumaila, UR, \& Le Billon, P. (2019) with their research title The Fisheries of Africa: Exploitation, policy, and maritime security trends. Likewise, with illegal logging, sea crossing, mapping, surveying, research and so on, which are under Indonesia's national jurisdiction to find out all events and conditions at sea level in a limited manner related to law Violations, disturbances, and threats to law enforcement and the sovereignty of the Republic of Indonesia. This is a security issue at sea, which includes the concepts of Geopolitics and Maritime Security, also raised by Germond, B. (2015) with the research title The geopolitical dimension of maritime security, a maritime patrol aircraft as one of the elements owned by the Indonesian Navy is a supporter in carrying out The duties and operations of the Indonesian Navy in the context of carrying out defense and security at sea, were also appointed by Chapsos, I., \& Malcolm, JA (2017) with the research title Maritime security in Indonesia. The existence of Maritime Patrol Aircraft at this time has helped a lot in the achievement of the success of Navy tasks and operations.

Various forms of marine security operations held manifested in the form of:

- Maritime security operations throughout the year, in the implementation of integrated Opskamla, divided into elements of the Navy, Police, and Customs are formally under the command Opskamla. Later that year-round operation was carried out by the appropriate authority of the functional agencies, respectively;

- Special operations carried out by the command of maritime security operations in an integrated manner in the operation area, time, and target specific operations.

Logistics is the process of a strategy in managing procurement, transfer, and storage, final inventory through the organization and company channels, so that current and future profits can be maximized through cost-effectiveness and order fulfillment costs (Firmanto, $\mathrm{H}$. 2006). Achieve targets at the lowest cost, with a mission to plan and coordinate all important activities. Management process from supplier, procurement, operation, distribution, the customer.

The hallmark of the goal programming method is the presence of a lot of goals to be achieved by decision-makers. Given the number of goals to be achieved, the performance objectives different from one another. Perhaps the achievement of a goal more than what has been defined as the criterion of success and goal achievement may also be less than what has been defined (deviation). Likewise, for other purposes within the framework of the same problems. A goal, in this case, is greater when the achievements of the success criteria are referred to as "over-achiever", while if performance goals are smaller than the success criteria referred to as "under-achievement". The advantages and disadvantages of Goal Programming according to (Mulyono, Sri. 1991) "Operations Research":

Advantages: 
- Each goal is represented in a model;

- All objectives can be included in the model;

- Decision-makers are encouraged to estimate levels. This gives more consideration to the modeling. This approach applies to a range of important and practical issues, including curve estimation and testing, pattern recognition and classification, and cluster analysis;

- Can be done in linear programming.

Weakness:

- It took more time to form the model;

- The involvement of decision-makers are more related to determining the level of aspirations, priorities, and so on;

- Considerations that are subjective in the setting of priorities and weights.

Fuzzy Inference System (FIS) also called Fuzzy Inference Engine is a system that works based on Fuzzy Logic (fuzzy logic) that can reason with similar principles as humans do reasoning with their instincts, research with FIS was also appointed by Ahmadi, A., Vanany, I., \& Koerniawan, H. (2015) with the research title Optimization of Maritime Patrol Aircraft Assignments to Support Koarmatim Opskamla Using Goal Programming Methods and Fuzzy Inference System, in the research that will be made using the Fuzzy Method is the Mamdani method with the help of Matlab R2014A tools, input variables, and output variables are divided into one or more fuzzy sets.

There are several known types of FIS, namely Mamdani, Sugeno, and Tsukamoto. The FIS that is easiest to understand, because it suits, human instincts the most is the Mamdani FIS. The Mamdani Method is often known as the Min-Max Method. This method was introduced by Ebrahim Mamdani in his 1975 research title. The FIS works based on linguistic principles and has a fuzzy algorithm that provides an approximation for entering the mathematical analysis. The input that is given to the FIS is in the form of a certain number and the resulting output must also be a certain number.

\section{METHODS OF RESEARCH}

Problem Identification. How to use Maritime Patrol Aircraft as an extension of the warship's eye, so that maritime security operations run optimally and by the rules of the Archipelago Marine Defense Strategy Concept (Naval Headquarters, 1994). Who patrol the operational sectors optimised by using the minimum budget possible to be able to support the implementation of maritime security operations in the working area of the Eastern Indonesian Fleet Command by Library Studies and Field Studies.

Library Studies and Field Studies. The literature study was carried out using a literature review of several literature that were correlated with the research theme. The use of literature studies is not only based on theory but also involves the studies that have been developed from these kinds of literature.

Field studies were conducted to obtain the data needed in this research. Field studies were carried out at the Indonesian Navy Aviation Center, including the Operations Staff, Planning Staff, Logistics Staff, and the Air Squadron as one of the executors of the Maritime Patrol Aircraft force. In addition, data is required from the Fleet Command in this case the Command and Control Center and the Fleet Command Operations Unit related to the Marine Security Operation Plan and Coverage Area data from the Integrated Maritime Surveillance System (IMSS).

Model Formulation. Formulation of the model is an activity model problem with mathematical models to become simpler and easier to understand step-by-step: Identify the decision variables (decision variables), the identification of limiting/constraints (constraint), and the determination of the objective function (objective function) (Hamdani A., 2003).

Data Collection. At this stage implemented data collection in the field. Data were included primary data and secondary data. Primary data is data obtained directly at the object under study, and interviews with staff operations and related the crew of Maritime 
Patrol Aircraft. Secondary data is data obtained from documents that already exist, such as the operating sector data, the database, the data plan of operation.

Model Validation. The Validation Model (suitability) is proving the truth or to determine or verify the accuracy of the model. Taha. H.A. (1996). Validation of the model (suitability) aims to check whether the model obtained from the optimization calculations are by the actual conditions in the field, but it is also as a comparison between the optimum conditions obtained from the model calculations were carried out with the real situation when the model has not been established. If there are still to be repaired, then returned to the stage of the model formulation.

Interpretation of Results. Interpretation and analysis of the results of data processing performed on a model that has been developed after the required data has been collected and processed. Interpretation is done to address the problem as it has been formulated and its relation to the fulfillment of the purpose of research.

\section{RESULTS AND DISCUSSION}

Maritime Patrol aircraft moving from place to place during operation have variable speed capability and radar range capability. Where the cruising distance of the maritime patrol aircraft is the range capability of the Maritime Patrol aircraft flying during operating hours/trips and the coverage area of the maritime patrol aircraft is the area that can be covered by the Maritime Patrol Aircraft in the operating area during operating hours/trips, Maritime Patrol aircraft data are needed in the implementation of operations, among others, are: Maritime Patrol aircraft type; Aircraft speed; Aircraft endurance; Hours of operation; Roaming distance (Surveillance, Radar ideal (nm), Real radar (nm).

In operating, financing, it is defined as the cost per-endurance of liquid logistics and aircraft personnel logistics during operations, the use of logistics, namely: Liquid logistics and personnel logistics where the use is as follows:

a. Liquid logistics: Fuel oil, Lubricant;

b. Personnel logistics: Operation meal money, Operation allowance, Tactical funds, Command and Control fund.

OTD (Operation Trip Days) is a count of the number of days it takes a unit of Maritime Patrol Aircraft to fly to carry out one operation route in the marine security Operations sectors. It should be determined that in one day the Maritime Patrol Aircraft flies for how many hours for one operation.

Initial data collection and calculation must be carried out, and the next step is to optimize the assignment of Maritime Patrol Aircraft to the operational sector. This stage includes the preparation of mathematical models and optimization processes. The formulation of the mathematical model and optimization process is carried out using the Integer Linear Programming theory, with stages, namely: (1) Determination of Decision Variables, (2) Determination of Objective Functions (3) Determining System Limits and (4) Optimization Process.

The optimization process is carried out using the Lingo 8.0 program, according to (Hamdan A. 2003). Operation Research, which has an unlimited constraint version with the aim that all types of existing constraints/constraints are expected so that the results obtained are more optimal. The sequence of steps is as follows:

a. Data Input and Compilation:

- Operation Sector Data (route length and operating sector area);

- Maritime Patrol Aircraft capabilities (speed, ideal and real radar range and maximum fuel tank capacity);

- Operating costs per day.

b. Preparation of Decision Variables:

- Matrix zero-one Maritime Patrol Aircraft assignment;

- Deviation Value.

c. Preparation of Objective Functions:

- Minimize the value of deviation/deviation; 
- Achievement of the maximum area (Coverage Area) of the radar (in Ideal and Real Performance conditions) the number of Maritime Patrol Aircraft in several operating/patrol sectors by minimizing operating costs.

Application of Fuzzy Logic method of Mamdani on the Determination of Operating Costs Maritime Patrol Aircraft Assignment Theoretically according to OTD (Operation Trip Days). Operation Trip Days (OTD) Maritime Patrol Aircraft in a sector will affect the ability of the resulting Coverage Area. To obtain a broad coverage area radar, the required number of aircraft that much in operation as well as increasing the Operation Trip Days (OTD) Maritime Patrol Aircraft in the sector. Of course, it will also raise the operational costs to be incurred, so that there is a correlation between the area of radar coverage aircraft in a sector with operational costs to be incurred. Increasingly wide/large coverage area to be achieved, the greater the operating costs to be incurred.

Uncertainty number of operating costs required in a particular sector because of differences in the number and type of aircraft that operate there, as well as the need coverage area radar at each different sector make the Fuzzy Logic method needed to be applied in this case. The application is later based on the results of theoretical calculations Coverage Area radar in each sector as well as operational costs in accordance Operation Trip Days (OTD) Maritime Patrol Aircraft in the sector.

Furthermore, by using the formula Mean Absolute Percentage Error (MAPE) we will calculate how much FIS forecasting accuracy with real data in the field, as follows.

$$
M A P E=\frac{\sum_{t=1}^{n} \frac{I Y_{t}-\overline{Y_{t}} I}{Y_{t}} \times 100}{n}
$$

Forecasting calculations with FIS will get an absolute error percentage or in other words, have a level of accuracy of truth to the data obtained from the field. So it can be concluded from the analysis that the Fuzzy calculation using the Mamdani method allows us to predict the operational costs that must be incurred on the assignment of the Maritime Patrol Aircraft theoretically by OTD (Operation Trip Days) if we want a Coverage Area with a certain area.

Model validation is to prove the truth or to determine or test the accuracy of the model. Model validation is carried out by comparing the optimization results with the reality in the field, a comparison between before and after optimization from this it can be concluded that the optimization model of the Maritime Patrol Aircraft assignment in this study, especially regarding efforts to increase Coverage Area, allows it to be applied to the Security Operations plan The sea in the future. The optimization of the assignment of the Maritime Patrol Aircraft to the patrol sector is expected to provide input to the Indonesian Navy regarding the operational pattern and the pattern of the Maritime Patrol Aircraft assignment.

\section{CONCLUSION}

The results of the optimization of the Maritime Patrol Aircraft Radar Coverage Area capability, if validation is carried out, will be greater than the previous Radar Coverage Area. So it can be concluded that there is an increase in Radar Coverage Area results after the data is optimized.

Optimal results for total operational costs will result in optimal results that are smaller than the use of the previous operating budget, and for total operational costs after going through the Optimization process. So it can be concluded that the total operational costs of the optimization results are smaller than the use of the operational budget before the optimization is carried out.

The results of the optimization of the assignment of Maritime Patrol Aircraft to the regional patrol sector when the conditions of Radar Perform Ideal with Radar Perform Real conditions will have differences in the results of the Coverage Area 
Other analysis results which will show that the uncertainty of the number of operational costs required in a particular sector due to the differences in the number and types of aircraft operating there, as well as the need for Radar Coverage Areas in each different sector makes the Fuzzy Logic method needed, to be applied in this case. . So that the Fuzzy calculation of the Mamdani method makes it possible to predict the operational costs that must be incurred on the assignment of the Maritime Patrol Aircraft theoretically under OTD (Operation Trip Days) if you want a Radar Coverage Area with a certain area. With the results of the accuracy analysis using the Mean Absolute Percentage Error (MAPE) in other words, the accuracy of the data obtained is better.

\section{SUGGESTIONS}

The results of the optimization process, with Maritime Patrol Aircraft are different and have wider coverage compared to other Maritime Patrol Aircraft, so it can be a consideration for prioritizing the assignment of Maritime Patrol type aircraft to be used in operations.

The optimization process in this study has not included intelligence data in the form of regional vulnerability factors, sea conditions in neighboring countries, and logistical capabilities at each supporting base in each patrol sector. It is recommended for further research to include some of these things into the calculation so that later research has a more complex multi-purpose area.

The deployment of Maritime Patrol Aircraft in eastern maritime security operations is very efficient. The "Sea Saw" operation pattern that has been implemented in the warships can be replaced with the "Wait Standby" pattern by prioritizing Maritime Patrol Aircraft as an element of surveillance, to reduce the operational costs of the warships.

\section{ACKNOWLEDGEMENTS}

The authors greatly acknowledge the support from the University of Brawijaya, (Malang, Indonesia) for providing the necessary resources to carry out this research work. The authors are also grateful to the anonymous reviewers and journal editorial board for their many insightful comments, which have significantly improved this article.

\section{REFERENCES}

1. Ahmadi, A., Vanany, I., \& Koerniawan, H. (2015). Optimasi Penugasan Pesawat Patroli Maritim Guna Mendukung Opskamla Koarmatim Dengan Metode Goal Programming and Fuzzy Inference System. Journal ASRO-STTAL-International Journal, 3, 14-22.Jalal, H. (2005). Wilayah Negara, Kedaulatan and Hukum Internasional. Makalah disampaikan pada Apel Komandan Satuan TNI AL.

2. Belhabib, D., Sumaila, U. R., \& Le Billon, P. (2019). The fisheries of Africa: Exploitation, policy, and maritime security trends. Marine Policy, 101, 80-92.

3. Bueger, C., \& Edmunds, T. (2020). Blue crime: Conceptualising transnational organized crime at sea. Marine Policy, 119, 104067.

4. Chapsos, I., \& Malcolm, J. A. (2017). Maritime security in Indonesia: Towards a comprehensive agenda?. Marine Policy, 76, 178-184.

5. Dikmen, M., Atalay, M., \& Gümüş, B. (2016). Role of the Unmanned Aircraft Systems in Maritime Security. American Scientific Research Journal for Engineering, Technology, and Sciences (ASRJETS), 26(3), 164-171.

6. Firmanto, H. (2006). Riset Operasi, Solver: Modul perkuliahan Transportasi Laut.

7. Germond, B. (2015). The geopolitical dimension of maritime security. Marine Policy, 54, 137-142.

8. Hamdan A. (2003). Operation Research, An Introduction Seventh Edition. Prentice-Hall. New Jersey USA.

9. Hamzah, A. (1984). Laut, teritorial and perairan Indonesia: himpunan ordonansi, undangundang and peraturan lainnya. Akademika Pressindo. 
10. HOU, Q. H., \& YAO, Y. P. (2018). Research on Modeling Maritime Patrol Behavior of Aircraft on Station in Theater-Level Operation Simulation. DEStech Transactions on Computer Science and Engineering, (CMSA).

11. Isak, R., Fanani, Z., Setyo, W., \& Tjahjanulin, D. Maritime Policy Integration Model at Natuna on The Defense and Security Perspective.

12. Kementerian Pertahanan, R. I. (2015). Buku putih pertahanan. Jakarta: Kemhan RI.

13. Kusumadewi, S., \& Purnomo, H. (2004). Aplikasi Logika Fuzzy untuk pendukung keputusan.Pendukung Keputusan. Graha Ilmu. Yogyakarta.

14. Liu, Y., Liu, Z., Shi, J., Wu, G., \& Chen, C. (2019). Optimization of base location and patrol routes for unmanned aerial vehicles in border intelligence, surveillance, and reconnaissance. Journal of Advanced Transportation, 2019.

15. Lutz, R. R. (2003). The Multi-mission Maritime Aircraft modeling and simulation environment. Johns Hopkins APL technical digest, 24(3), 284-291.Lobo, Victor. (2003), One Dimensional Self-Organizing Maps To Optimize Marine Patrol Activities, Portuguese Naval Academy. Lisboa

16. Mabes AL. (1994) Konsep Strategi Pertahanan Laut Nusantara. Jakarta.

17. Mabes AL. (2002). Konsep Operasi TNI AL Dalam Rangka Penegakan Kedaulatan and Keamanan Laut, Staf Operasi Kasal, SOPS FPSO, Surabaya.

18. Mabes AL. (2009). Peraturan Kasal nomor Perkasal/35/V/2009 tanggal 19 Mei 2009 tentang Organisasi and Prosedur Pusat Penerbangan TNI AL. Kasal. Jakarta.

19. Marsetio, B. (2014). Manajemen Strategis Negara Maritim dalam Persepektif Ekonomi and Pertahanan.

20. Minglu, M., \& Guobo, W. (2020, October). Key factors analysis of maritime patrol in maritime safety management based on fuzzy analytic hierarchy process. In IOP Conference Series: Earth and Environmental Science (Vol. 585, No. 1, p. 012056). IOP Publishing.

21. Mulyono, Sri. 1991. "Operations Research". Fakultas Ekonomi Universitas Indonesia. Jakarta.

22. Puntenney, Michael. (1989). Optimization Models For Military Aircraft Deployment, Thesis Naval Postgraduate School, Monterey.CA.

23. Sudarsan, B., Subramani, K., \& Dillikumar, P. (2013). Marine Conservation Zone Surveillance Using Image Processing. APCBEE procedia, 5, 394-399.

24. Taha, H. A. (1996). Riset Operasi: suatu pengantar, jilid 1.

25. Yadav, Bharti. (2011) An Algorithm to Solve Multi-Objective Assignment Problem Using Interactive Fuzzy Goal Programming Approach, International Journal Mathematics Sciences Volume 6. India. 